\title{
Effect of decompression on mesopelagic gelatinous zooplankton: a comparison of in situ and shipboard measurements of metabolism
}

\author{
T. G. Bailey ${ }^{1}$, J. J. Torres ${ }^{2}$, M. J. Youngbluth ${ }^{1}$, G. P. Owen ${ }^{1}$ \\ ${ }^{1}$ Harbor Branch Oceanographic Institution, 5600 U.S. 1 North, Fort Pierce, Florida 34946, USA \\ ${ }^{2}$ Department of Marine Science, University of South Florida, 140 Seventh Ave. South, St. Petersburg, Florida 33701, USA
}

\begin{abstract}
Weight- and carbon-specific rates of respiration for 4 mesopelagic gelatinous zooplankton ( 2 ctenophores, 1 trachymedusa and 1 pelagic holothurian) measured in situ were 2 to 5 times higher than those from shipboard incubations. These results support the theory that removal of deep-living gelatinous species from natural environments can adversely affect their metabolism. The disparity between in situ and shipboard treatments is most simply explained by an interaction between pressure and activity, i.e. a loss of motor activity due to decompression occurred among animals used in shipboard experiments.
\end{abstract}

KEY WORDS: Gelatinous zooplankton - Metabolism · Pressure

\section{INTRODUCTION}

Gelatinous organisms are a conspicuous and widespread component of oceanic communities to depths of at least $1000 \mathrm{~m}$, often reaching very high abundances (Youngbluth et al. 1990). For example, studies conducted in 2 deep basins (East Cortes and San Clemente) off southern California, USA, revealed that the pelagic holothurian Scotoanassa sp. and other gelatinous species dominated the biomass and total metabolism of macrozooplankton within the benthic boundary layer (Childress et al. 1989). Similarly, Smith (1982) noted that the macrozooplankton collected within $50 \mathrm{~m}$ of the bottom in the Santa Catalina Basin (also off southern California) was composed almost entirely of gelatinous animals (siphonophores, ctenophores, and scyphomedusae). In the subtropical Atlantic, gelatinous species were consistently the most visually prominent macrozooplankton in midwater and benthic boundary regions during submersible dives along the south coast of Grand Bahama Island (1989 and 1990) and St. Croix, USVI (1989 and 1991), and off the north coast of Jamaica (1993) (Bailey unpubl. data). Their ubiquitous distribution and periodic numerical dominance in midwater and benthic boundary layer communities (e.g. Wiebe et al. 1979, Kremer et al. 1994, Madin et al. 1994) suggest that the metabolism of gelatinous animals is a significant factor in deep-sea carbon flow.

Two basic approaches have been used to determine physiological characteristics of deep-sea animals: (1) measurements in shipboard laboratories and (2) quantification in the natural environment. Because of the delicate nature of most midwater gelatinous zooplankton, their metabolic rates may be affected by the physical stresses incurred during the ascent to the surface or the shipboard handling required for laboratory experiments.

This paper presents data which support the theory that rates of oxygen consumption of deep-living gelatinous zooplankton are affected significantly by the stresses mentioned. Results from in situ experiments were compared with shipboard measurements of animals which were not manipulated prior to incubation and with animals which were transferred from collectors before incubation (i.e. manipulated). In addition to the physiological aspects, these data serve to establish a baseline for defining the trophic roles and relative contributions of gelatinous zooplankton to carbon cycling and transport in deep-sea communities. 


\section{MATERIALS AND METHODS}

Experiments were conducted during 2 cruises (December 1990 and March 1991) with a Johnson-SeaLink (JSL) submersible off Sweetings Cay along the southeast coast of Grand Bahama Island, Bahamas $\left(26^{\circ} 30^{\prime} \mathrm{N}, 78^{\circ} 08^{\prime} \mathrm{W}\right.$; Fig. 1). Gelatinous zooplankton (ctenophores, medusae, and pelagic holothurians) were sampled within $50 \mathrm{~m}$ of the bottom (bottom depth range $=735$ to $900 \mathrm{~m}$ ). Temperature, salinity and oxygen content measured at the sampling depths varied from 8.2 to $11.0^{\circ} \mathrm{C}, 32.5$ to $33.3 \%$ and 5.14 to $5.62 \mathrm{ml}$ $\mathrm{O}_{2} \mathrm{l}^{-1}$, respectively.

Eight custom-designed respirometers mounted on the submersible were used to gently trap gelatinous zooplankton. The respirometers are modified versions of the JSL passive samplers used for the past $10 \mathrm{yr}$ to capture intact specimens of the most fragile zooplankton (Youngbluth 1984). The samplers consisted of clear acrylic tubes $(1.3 \mathrm{~cm}$ thick $\times 16.5 \mathrm{~cm}$ ID) with lengths (either $30.5 \mathrm{~cm}$ or $15.3 \mathrm{~cm}$ ) varying according to volume (6.5 l and $3.3 \mathrm{l}$ ) in the 2 sizes that were used. The acrylic cylinders and lids provided sufficient insulation to maintain in situ temperatures within the respirometers during ascent to the surface and during the 10 to $15 \mathrm{~min}$ period required after recovery to transfer them to the temperature-controlled chamber aboard ship.

Both arrays of 8 respirometers were deployed daily (2 dives per day; 1 deployment per dive). One array was detached from the submersible and incubated in situ. The other was returned to the surface where samplers were incubated in shipboard environmental chambers at in situ temperatures. In the third experimental treatment, gelatinous animals were collected

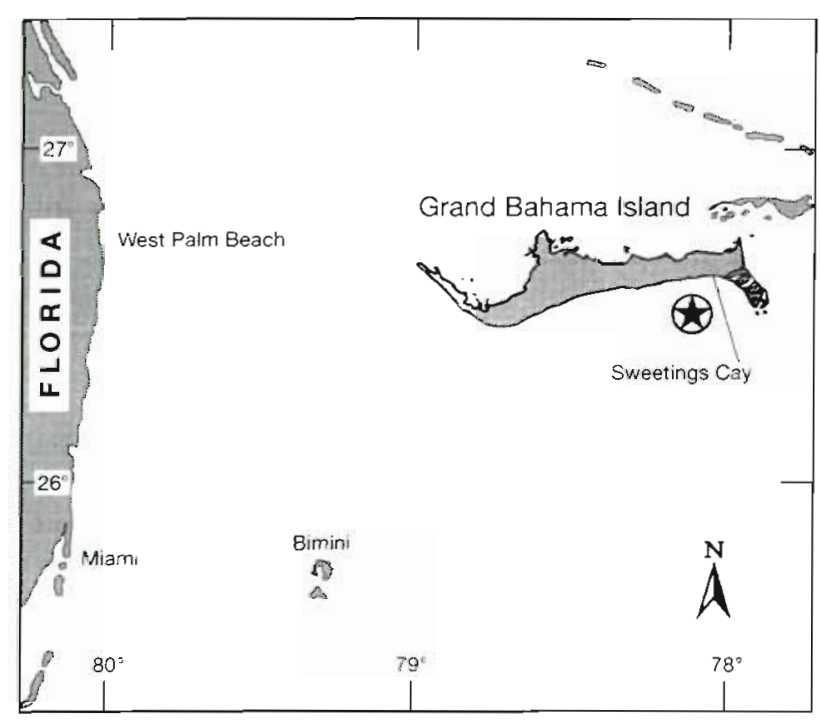

Fig. 1 Grand Bahama Island and the coast of Florida. The study site, off Sweetings Cay, is marked with a star with the JSL's multiple-bin suction sampler (Youngbluth 1984), returned to the surface and transferred to water-jacketed respirometers for incubation aboard ship. Either 6 or 7 of the 8 respirometers were used on each dive to collect animals. The remaining respirometers served as controls; water was collected from the same depth as that of the experimental animals.

For in situ incubations, after the animals and controls had been collected, the array of respirometers was attached to a moored line at a predetermined midwater depth, then detached from the submersible and left to incubate in situ for periods ranging from 12 to $20 \mathrm{~h}$. Incubation depths were 5 to $7 \mathrm{~m}$ above the bottom (range $=680$ to $840 \mathrm{~m}$ ). Recovery of the array was accomplished by detaching an expendable anchor from the moored line with an acoustic release. Subsurface buoys brought the array to the surface where it was recovered with the support vessel.

For shipboard incubations, once the animals and controls had been collected in the JSL respirometers (identical to in situ respirometers), the submersible made a slow ascent to the surface. Aboard ship, each respirometer was quickly detached from the submersible and transferred to an environmental room maintained at $9 \pm 1^{\circ} \mathrm{C}$. Incubations were conducted in the dark.

Three types of oxygen sensors were used: (1) in situ measurements were made with Nester oxygen sensors (general purpose D.O. probe; Leeds and Northrup Corp.); (2) shipboard incubations of JSL respirometers were made using Endeco pulsed oxygen electrodes (type 1128 D.O. probe; YSI); and (3) specimens collected with the suction sampler were incubated aboard ship in water-jacketed acrylic respirometers with microcathode Clark-type oxygen electrodes manufactured in our laboratory (Mickel et al. 1983). These microcathode Clark-type electrodes were made with a $15 \mu \mathrm{m}$ diameter cathode. Because the oxygen requirements of these small-diameter cathodes can easily be satisfied by unaided diffusion of oxygen through the membrane, low-oxygen boundary layers do not form at the membrane and thus, stirring was not required (Baumgärtl \& Lübbers 1983)

Both Nester and Endeco probes met our criteria for use in the in situ respirometers, i.e. neither probe required stiring, and both were stable and sensitive enough to measure low rates of oxygen consumption by animals such as midwater gelatinous zooplankton. However, both probe types were affected by rapid changes in pressure and temperature, thus precluding in situ measurements during descent or ascent. Furthermore, only the Nester probes stabilized at depth quickly enough for in situ experiments. After a slow descent to depths of 300 to $900 \mathrm{~m}$. Nester probes stabilized within a period of $2 \mathrm{~h}$ (Fig. 2). On the other 
hand, Endeco probes, when exposed to pressures reaching $100 \mathrm{~atm}$ (ca $1000 \mathrm{~m}$ ), required a minimum of 6 to $7 \mathrm{~h}$ to stabilize. Monetary constraints were responsible for our selection of Endeco, rather than Nester probes, for shipboard incubations. Laboratory experiments at our shore-based pressure test facility demonstrated that, once stabilized, there were no significant effects of hydrostatic pressure on the response of Nester sensors. Output voltages of Nester probes exposed to pressures ranging from 1 to $100 \mathrm{~atm}$ were not significantly different ( $p>0.05$; ANOVA). Further, respiration for each of 5 species of gelatinous zooplankton measured simultaneously in shipboard incubations with both Nester and Endeco probes were not significantly different ( $\mathrm{p}>0.05 ;$ t-test).

Output voltages from the Nester probes were recorded with a solid-state datalogger (SeaBird Electronic Sealogger SBE-20) mounted on the sampling array framework. Endeco probes were installed in the respirometers prior to a dive, but were not powered-up until the respirometers had been placed in the environmental chamber. The pulse interval for the Endeco probes was $15 \mathrm{~min}$. Because Endeco probes were profoundly affected by rapid changes in temperature and
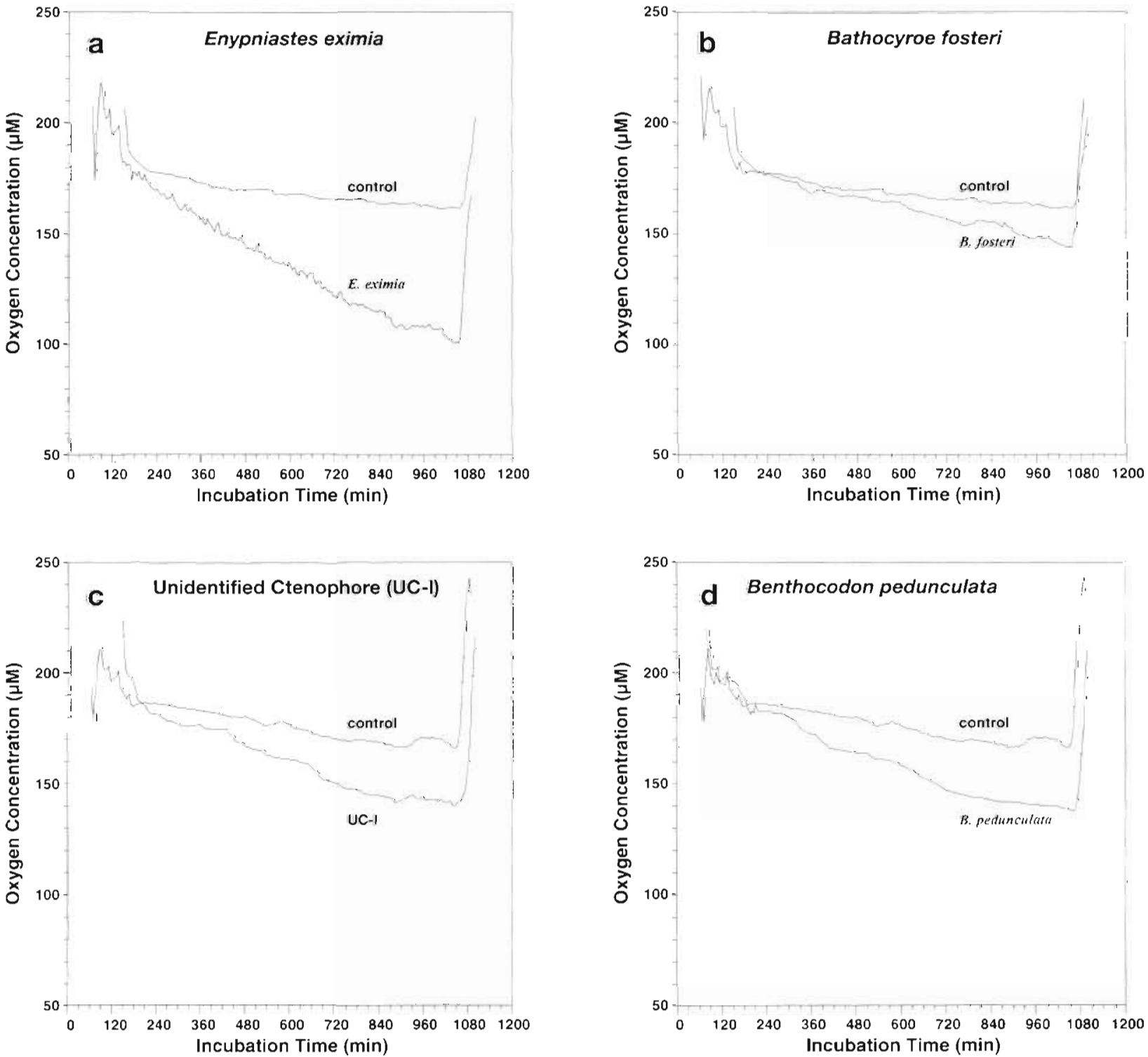

Fig. 2. Typical respiration runs for (a) Enypniastes eximia, (b) Bathocyroe fosteri, (c) unidentified ctenophore (UC-I), and (d) Benthocodon pedunculata. Data from the appropriate control respirometers are included for each run. The first part of each experiment, which includes pre-dive preparation and the descent portion of the dive, is not shown. Oxygen concentrations within respirometers are plotted as a function of incubation time beginning at the point when probe outputs became submaximal 
pressure, a period of 3 to $5 \mathrm{~h}$ was required for restabilization of the probes subsequent to each dive. Consequently, data obtained during this restabilization period were not used. Outputs from the Endeco sensors were recorded with an Onset Tattletale datalogger. Data from the microcathode Clark-type probes were recorded on a computer-controlled datalogging system (Torres \& Somero 1988). Linearity in the response of electrodes to different oxygen concentrations was established using both oxygen saturated and deoxygenated (nitrogen stripped) water

After each experiment, subsamples were withdrawn from each respirometer for determinations of ammonia and phosphate (Strickland \& Parsons 1972). Ambient in situ levels of ammonia and phosphate were established from samples taken at depth through the submersible's pressure relief valve. Both experimental and control levels of ammonia and phosphate were corrected for ambient in situ levels. Excretion rates of ammonia and phosphate were determined by subtracting control from experimental values. All samples were analyzed at sea within $12 \mathrm{~h}$ of collection.

After subsampling for excretory products, animals were measured in situ (i.e. while still inside the respirometer) to the nearest $0.5 \mathrm{~mm}$, blotted using the technique described by Youngbluth et al. (1988), and frozen in sealed tared jars at $-10^{\circ} \mathrm{C}$. In the laboratory ashore, jars containing the animals were weighed to the nearest $0.01 \mathrm{~g}$ and then specimens were dried at $60^{\circ} \mathrm{C}$ to constant weight. Subsequently, the dried samples were homogenized for analyses of CHN and ash weight.

\section{RESULTS}

In situ rates of oxygen consumption were recorded for 58 individuals representing 6 species during the 1990 cruise: a pelagic holothurian (Enypniastes eximia), 2 lobate ctenophores (Bathocyroe fosteri and an undescribed species, UC-I ${ }_{i}$ Harbison unpubl.), a cydippid ctenophore (Agmayeria tortugensis), and 2 medusae (Benthocodon pedunculata and Solmissus sp.). Data from shipboard respiration runs conducted in 1990 were invalid due to technical problems. During the 1991 cruise, respiration rates were recorded for 49 individuals representing 4 species (17 individuals, 3 species in situ; 32 individuals, 4 species shipboard) using the JSL respirometers: E eximia, B. fosteri, UC-I, and $B$. pedunculata. Shipboard rates were also determined using water-jacketed respirometers for 20 individuals representing 2 species during the 1991 cruise: E. eximia and B. pedunculata. Four species of gelatinous animals were common to both cruises in sufficient numbers for statistical analyses: E eximia, B. fosteri, UC-I and B. pedunculata.

\section{Species descriptions}

Enypniastes eximia (Order: Elasipodida; Family: Pelagothuridae) is a benthopelagic holothurian which is cosmopolitan at depths of 516 to $5689 \mathrm{~m}$ (Miller \& Pawson 1990). Individuals swim or float just above the bottom, but depend on sediments for sustenance. The integument of $E$. eximia is intensely bioluminescent, which is theorized to be an antipredator mechanism (Robison 1992). This and other pelagic holothurian species can dominate the megafaunal biomass at some localities in the bathyal-abyssal zone (Barnes et al. 1976). As a group, benthopelagic holothurians are important for their ability to rework and transport surface sediments for considerable distances, both horizontally and vertically, from the source area (Billett et al. 1985, Billett 1986).

Bathocyroe fosteri is a lobate ctenophore common at midwater depths below $200 \mathrm{~m}$ and at water temperatures below $11^{\circ} \mathrm{C}$ in the NW Atlantic (Madin \& Harbison 1978). Specimens captured in the Bahamas differ somewhat from the line drawings in the original description (Youngbluth et al. 1988). Prey found in the guts of $B$. fosteri include copepods and euphausiids. $B$. fosteri is quite responsive to incandescent light. When exposed to the submersible's lights, it usually shrinks noticeably in overall size, particularly in the region of the aboral crown where the short comb-rows occur, and, if encountered in the inverted position, it contracts its outspread oral lobes and tumbles around to the upright position. Turbulence generated by the movement of the submersible or its thrusters can often induce the ctenophore to swim briefly by slowly flapping its oral lobes.

The undescribed ctenophore UC-I superficially resembles the lobate ctenophore Bolinopsis infundibulum in having variegated structures within its lobes. It is one of the largest lobate ctenophores encountered at midwater depths in Bahamian waters.

The trachymedusa Benthocodon pedunculata is a benthopelagic species which usually occurs within $10 \mathrm{~m}$ of the bottom at depths from 800 to $1000 \mathrm{~m}$ (Larson et al. 1992, pers. obs.). Observations from submersibles and remotely operated vehicles indicate that $B$. pedunculata can occur at densities up to 80 medusae $\mathrm{m}^{-2}$ (Larson et al. 1992). In the Caribbean (Bahamas and St. Croix, USVI) this species was frequently observed directly on the bottom (depth $=800$ to $900 \mathrm{~m}$ ), using its tentacles to glide across the substratum. Gut analyses have shown these medusae to feed on both benthopelagic and benthic organisms, although the predominant prey items were benthopelagic crustaceans (G. I. Matsumoto pers. comm.). 
Table 1. Means and ranges for morphometric measurements of gelatinous zooplankton used in respiration experiments. Length/diameter (length along the longitudinal axis for Enypniastes eximia and ctenophores, bell diameter for Benthocodon pedunculata) was determined at the conclusion of each respiration run, while the specimens were still in the respirometers. n: number of individuals analyzed. Numbers in parentheses are standard deviations

\begin{tabular}{|c|c|c|c|c|c|c|c|c|c|}
\hline \multirow[t]{2}{*}{ Species } & \multirow[t]{2}{*}{$\mathrm{n}$} & \multicolumn{2}{|c|}{ Length or diameter $(\mathrm{mm})$} & \multicolumn{2}{|c|}{ Wet weight $(g)$} & \multicolumn{2}{|c|}{ Dry weight $(\mathrm{g})$} & \multicolumn{2}{|c|}{ Carbon content (mg) } \\
\hline & & Mean & Range & Mean & Range & Mean & Range & Mean & Range \\
\hline $\begin{array}{l}\text { Enypniastes } \\
\text { eximia }\end{array}$ & 58 & $\begin{array}{c}131.6 \\
( \pm 33.97)\end{array}$ & $55-250$ & $\begin{array}{c}284.9 \\
( \pm 228.24)\end{array}$ & $22.8-919.9$ & $\begin{array}{c}11.3 \\
( \pm 8.91)\end{array}$ & $1.0-34.3$ & $\begin{array}{c}171.2 \\
( \pm 161.00)\end{array}$ & $15.9-682.8$ \\
\hline $\begin{array}{l}\text { Bathocyroe } \\
\text { fosteri }\end{array}$ & 27 & $\begin{array}{c}45.6 \\
( \pm 10.18)\end{array}$ & $18-89$ & $\begin{array}{c}49.7 \\
( \pm 38.04)\end{array}$ & $3.1-126.6$ & $\begin{array}{c}1.9 \\
( \pm 1.51)\end{array}$ & $0.1-5.0$ & $\begin{array}{c}8.2 \\
( \pm 6.24)\end{array}$ & $0.5-22.5$ \\
\hline UC-I & 16 & $\begin{array}{c}139.9 \\
( \pm 20.72)\end{array}$ & $95-180$ & $\begin{array}{r}463.8 \quad \\
( \pm 149.12)\end{array}$ & $183.9-747.2$ & $\begin{array}{c}18.4 \\
( \pm 5.88)\end{array}$ & $7.2-29.2$ & $\begin{array}{c}90.5 \\
( \pm 38.12)\end{array}$ & $27.2-181.2$ \\
\hline $\begin{array}{l}\text { Benthocodon } \\
\text { pedunculata }\end{array}$ & 23 & $\begin{array}{c}23.7 \\
( \pm 6.62)\end{array}$ & $6-35$ & $\begin{array}{c}4.7 \\
( \pm 2.11)\end{array}$ & $1.7-8.4$ & $\begin{array}{c}0.2 \\
( \pm 0.10)\end{array}$ & $0.1-0.4$ & $\begin{array}{c}24.4 \\
( \pm 14.92)\end{array}$ & $5.5-53.3$ \\
\hline
\end{tabular}

\section{Morphometrics}

All expressions of physiological rates are based on measured weights. Means and ranges for morphometric parameters are given in Table 1. Regressions and correlations between weight and linear measures (e.g. length and bell diameter) are also presented for comparison with literature values (Table 2). However, because the bodies of most gelatinous animals are elastic, linear measures are not always reliable as standardization parameters (Youngbluth et al. 1988). Total length (TL) was significantly correlated with dry weight (DW) for Enypniastes eximia and Benthocodon pedunculata ( $\mathrm{p}<0.05$, productmoment correlation). Correlations between TL and DW were significant, but not as strong with Bathocyroe fosteri and UC-I. There were significant correlations between wet weight, dry weight, ashfree dry weight, and carbon content of all 4 species (Table 2).

\section{Elemental composition}

Mean carbon values, as a function of dry weight, ranged from 0.4 to $10.4 \%$ (Table 3 ). C: $N$ ratios varied from 3.1 for Benthocodon pedunculata to 4.7 for Enypniastes eximia (Table 3). These values are comparable to similar data reported for epipelagic and mesopelagic gelatinous zooplankton (Kremer 1975, Reeve \& Baker 1975, Reeve et al. 1978. Hoeger 1983, Kremer et al. 1986, Youngbluth et al. 1988, Childress et al. 1989).

\section{Oxygen consumption}

Weight-specific oxygen consumption was correlated positively $(\mathrm{p}<0,05$; Pearson product-moment correlation) with incubation time, indicating that experimental animals remained healthy throughout the respiration trials. Decreases in oxygen content of water in

Table 2. Morphometric regressions and correlations. Linear regressions of log-log transformed data $\left(Y=a X^{b}\right)$ were used to derive the slopes (b) and intercepts (a) for the relationships between dry weight (DW) and total length/diameter (TL/D). Relationships between DW and wet weight (WW), ash-free dry weight (AFDW) and carbon content (CC) were derived from linear regressions of untransformed data $\left(Y=a+b X\right.$; where $b=$ slope and $a=$ intercept). The coefficient of determination $\left(\mathrm{r}^{2}\right)$ is given for each regression. $\mathrm{n}$ : number of individuals analyzed

\begin{tabular}{|c|c|c|c|c|c|c|c|c|c|c|c|c|c|c|c|c|}
\hline \multirow[t]{2}{*}{ Species } & \multicolumn{4}{|c|}{$\mathrm{DW}(\mathrm{mg})=a \times[\mathrm{TL} / \mathrm{D}(\mathrm{mm})]^{b}$} & \multicolumn{4}{|c|}{$D W(m g)=a+b[W W(m g)]$} & \multicolumn{4}{|c|}{$\mathrm{DW}(\mathrm{mg})=a+b[\mathrm{AFDW}(\mathrm{mg})]$} & \multicolumn{4}{|c|}{$\mathrm{DW}(\mathrm{mg})=a+b[\mathrm{CC}(\mathrm{mg})$} \\
\hline & $a$ & $b$ & $r^{2}$ & $\mathrm{n}$ & a & $b$ & $r^{2}$ & $\mathrm{n}$ & $a$ & $b$ & $\mathrm{I}^{2}$ & $\mathrm{n}$ & a & $b$ & $\mathrm{r}^{2}$ & $\mathrm{n}$ \\
\hline $\begin{array}{l}\text { Enypniastes } \\
\text { eximia }\end{array}$ & 0.35 & 2.15 & 0.843 & 67 & 254.11 & 0.04 & 0.989 & 50 & 2.46 & 5.22 & 0.941 & 33 & 5581.53 & 49.07 & 0.791 & 50 \\
\hline $\begin{array}{l}\text { Bathocyroe } \\
\text { fosteri }\end{array}$ & 0.22 & 2.24 & 0.767 & 70 & -12.65 & 0.04 & 0.983 & 27 & 6.54 & 6.03 & 0.964 & 23 & 75.81 & 226.74 & 0.884 & 27 \\
\hline UC-I & 19.42 & 1.39 & 0.408 & 18 & 123.76 & 0.04 & 0.995 & 16 & 4.35 & 6.16 & 0.955 & 14 & 6433.12 & 132.36 & 0.734 & 16 \\
\hline $\begin{array}{l}\text { Benthocodon } \\
\text { pedunculata }\end{array}$ & 0.15 & 2.27 & 0.902 & 26 & 1.64 & 0.05 & 0.993 & 15 & 0.16 & 3.68 & 0.996 & 4 & 106.54 & 5.97 & 0.712 & 14 \\
\hline
\end{tabular}


Table 3. Water content ( $\%$ wet weight) and chemical composition ( $\%$ dry weight). Values shown are the means with standard deviations (SD) and number of individuals (n) analyzed in parentheses. $C=$ carbon, $N=$ nitrogen

\begin{tabular}{|c|c|c|c|c|c|}
\hline \multirow[t]{2}{*}{ Species } & \multirow[t]{2}{*}{ Treatment } & \multirow[t]{2}{*}{$\% \mathrm{H}_{2} \mathrm{O}$} & \multicolumn{3}{|c|}{ Composition as $\%$ of dry weight $(\mathrm{SD}, \mathrm{n})$} \\
\hline & & & $\% \mathrm{C}$ & $\% \mathrm{~N}$ & $C: N$ \\
\hline \multirow[t]{2}{*}{ Enypniastes eximia } & In situ & $96.01(0.39,31)$ & $1.11(0.39,31)$ & $0.25(0.11,31)$ & $4.50(0.50,31)$ \\
\hline & Shipboard & $96.06(0.12,15)$ & $1.08(0.50,15)$ & $0.23(0.12,15)$ & $4.71(1.28,15)$ \\
\hline \multirow[t]{2}{*}{ Bathocyroe fosteri } & In situ & $96.09(0.34,23)$ & $0.43(0.10,23)$ & $0.14(0.24,23)$ & $3.16(1.53,23)$ \\
\hline & Shipboard & $95.99(0.03,3)$ & $0.44(0.09,3)$ & $0.13(0.05,3)$ & $3.61(0.55,3)$ \\
\hline \multirow[t]{2}{*}{$\mathrm{UC}-\mathrm{I}$} & In situ & $96.01(0.07,11)$ & $0.51(0.13,11)$ & $0.16(0.03,11)$ & $3.28(0.46,11)$ \\
\hline & Shipboard & $96.08(0.11,5)$ & $0.44(0.07,5)$ & $0.14(0.02,5\}$ & $3.16(0.38,5)$ \\
\hline \multirow[t]{2}{*}{ Benthocodon pedunculata } & In situ & $95.31(0.09,5)$ & $8.20(0.42,5)$ & $2.69(0.40,5)$ & $3.09(0.38,5)$ \\
\hline & Shipboard & $95.26(0.14,8)$ & $10.41(3.25,8)$ & $3.02(0.91,8)$ & $3.44(0.11,8)$ \\
\hline
\end{tabular}

control chambers during incubation were significant $(\mathrm{p}<0.05$; paired $t$-test). Because no effort was made to filter the water used in the respirometers, consumption of oxygen in controls was presumed to be due to microzooplankton (e.g. tintinnids) and microorganisms (e.g. bacteria). It was further assumed that similar levels of consumption by these organisms were included in experimental respirometers. Differences in the rates of decrease of oxygen content between controls and experimental respirometers were significant in every case $(\mathrm{p}<0.01$; $t$-test; Fig. 2$)$.

There were no significant differences between the in situ weight-specific rates of respiration measured during the 1990 and 1991 cruises for Enypniastes eximia, Bathocyroe fosteri and Benthocodon pedunculata ( $\mathrm{p}>0.05$; $t$-test); in situ measurements were not made for UC-I in 1991. Therefore, in situ data from the 2 cruises were pooled by species. Rates of oxygen consumption using Endeco probes and Clark-type electrodes were not significantly different in shipboard incubations for the 2 species common to both systems (Enypniastes eximia and Benthocodon pedunculata; $p>0.05$, $t$-test). These data suggest that, at least for these 2 species, suction during collection and handling during transfer to respirometers aboard ship do not significantly affect rates of respiration in shipboard incubations.

Weight- and carbon-specific rates of respiration for all 4 species measured in situ were ca 2 to 5 times higher than those from shipboard incubations (Figs. 3 $\& 4$, Table 4). These differences were highly significant ( $p<0.02$ for each species; $t$-test). There were no significant differences in exponents (slopes) of allometric equations, derived from linear regressions of log-log transformed data $\left(Y=a X^{b}\right)$ on oxygen consumption as a function of wet weight, between in situ and shipboard incubations for each species ( $p<0.10, t$-test of slopes; Zar 1984). After computing a common allometric exponent for each species, the effect of weight on respiration was eliminated by dividing individual oxygen consumption values by a weight-normalization factor $\left(W^{b}\right.$; where $W$ is the individual wet weight, and $b$ is the computed common slope). There were significant differences in these weight-normalized values between in situ and shipboard incubations for each species ( $\mathrm{p}<0.10, t$-test). Because we found: (1) no significant differences between the responses of Nester and Endeco probes during shipboard incubations of

Table 4. Mean weight-specific and carbon-specific oxygen consumption rates. Values in parenthesis are the standard deviation (SD) and the number of individuals ( $\mathrm{n}$ ) analyzed

\begin{tabular}{|c|c|c|c|c|c|c|}
\hline Species & $\mu \mathrm{O}_{2} \mathrm{~g}^{-1} W W \mathrm{~h}^{-1}$ & $\begin{array}{c}\text { In situ } \\
\mu_{\mathrm{O}_{2} \mathrm{mg}^{-1} \mathrm{DWh}^{-1}}\end{array}$ & $\mu \mathrm{lO}_{2} \mathrm{mg}^{-1} \mathrm{Ch}^{-1}$ & $\mu \mathrm{O}_{2} \mathrm{~g}^{-1} W W \mathrm{~h}^{-1}$ & $\begin{array}{c}\text { Shipboard } \\
\mathrm{\mu lO}_{2} \mathrm{mg}^{-1} \mathrm{DWh}^{-1}\end{array}$ & $\mu \mathrm{lO}_{2} \mathrm{mg}^{-1} \mathrm{Ch}^{-1}$ \\
\hline $\begin{array}{l}\text { Enypniastes } \\
\text { eximia }\end{array}$ & $\begin{array}{c}0.815 \\
( \pm 0.546,31)\end{array}$ & $\begin{array}{c}0.038 \\
( \pm 0.033,31)\end{array}$ & $\begin{array}{c}4.013 \\
( \pm 3.786,31)\end{array}$ & $\begin{array}{c}0.307 \\
( \pm 0.149,27)\end{array}$ & $\begin{array}{c}0.009 \\
( \pm 0.005,27)\end{array}$ & $\begin{array}{c}0.746 \\
( \pm 0.676,19)\end{array}$ \\
\hline $\begin{array}{l}\text { Bathocyroe } \\
\text { fosteri }\end{array}$ & $\begin{array}{c}3.057 \\
( \pm 1.495,24)\end{array}$ & $\begin{array}{c}0.076 \\
( \pm 0.044,24)\end{array}$ & $\begin{array}{c}19.157 \\
( \pm 13.262,24)\end{array}$ & $\begin{array}{c}0.456 \\
( \pm 0.208,3)\end{array}$ & $\begin{array}{c}0.032 \\
( \pm 0.031,3)\end{array}$ & $\begin{array}{c}6.601 \\
( \pm 5.240,3)\end{array}$ \\
\hline $\mathrm{UC}-\mathrm{I}$ & $\begin{array}{c}0.628 \\
( \pm 0.159,11)\end{array}$ & $\begin{array}{c}0.015 \\
( \pm 0.007,11)\end{array}$ & $\begin{array}{c}3.373 \\
( \pm 1.605,11)\end{array}$ & $\begin{array}{c}0.191 \\
( \pm 0.108,5)\end{array}$ & $\begin{array}{c}0.005 \\
( \pm 0.002,5)\end{array}$ & $\begin{array}{c}1.080 \\
( \pm 0.552,5)\end{array}$ \\
\hline $\begin{array}{l}\text { Benthocodon } \\
\text { pedunculata }\end{array}$ & $\begin{array}{c}26.639 \\
( \pm 5.067,5)\end{array}$ & $\begin{array}{c}0.569 \\
( \pm 0.110,5)\end{array}$ & $\begin{array}{c}6.928 \\
( \pm 1.263,5)\end{array}$ & $\begin{array}{c}8.461 \\
( \pm 4.511,17)\end{array}$ & $\begin{array}{c}0.250 \\
( \pm 0.140,17)\end{array}$ & $\begin{array}{c}1.818 \\
( \pm 2.453,9)\end{array}$ \\
\hline
\end{tabular}



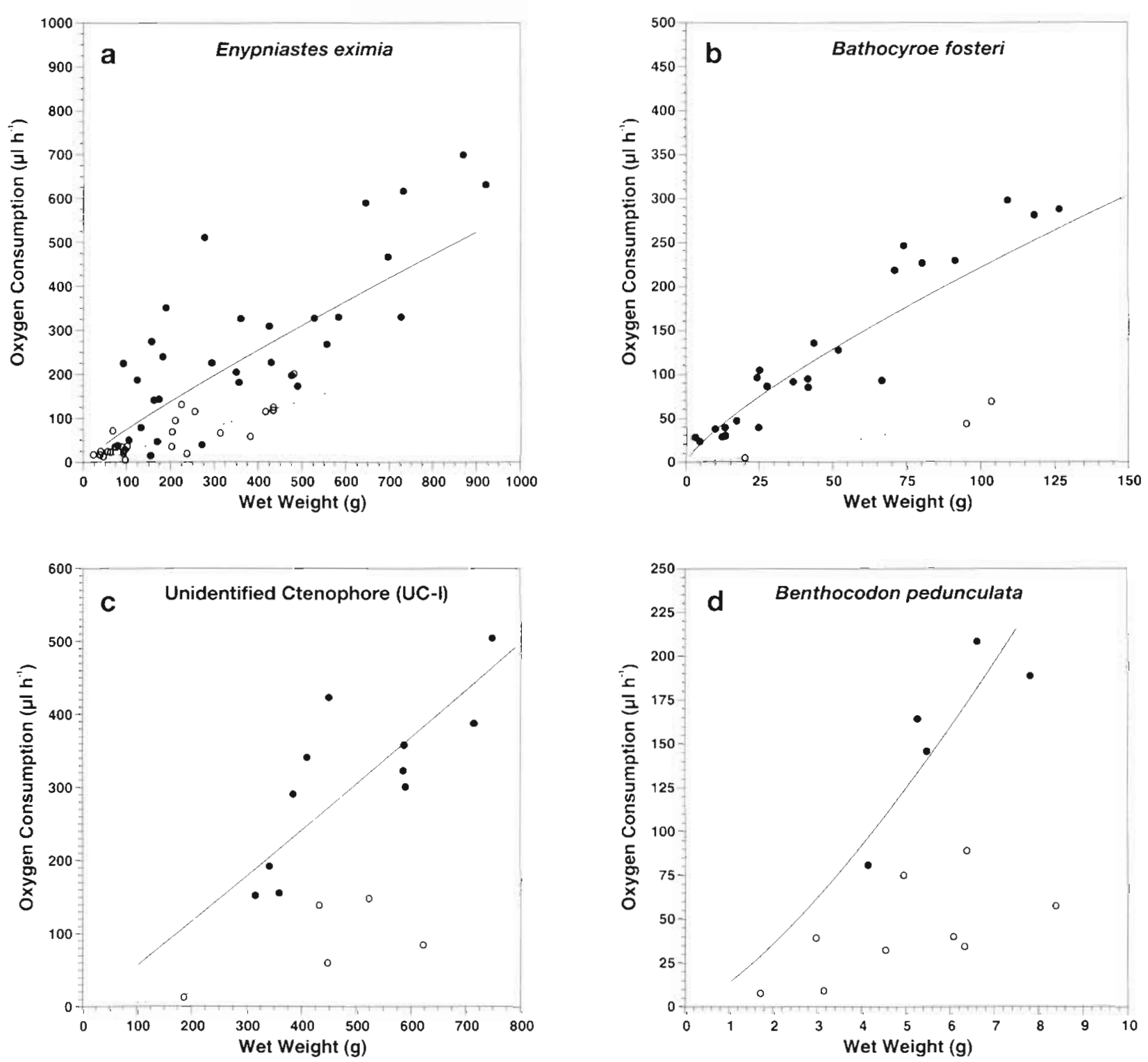

Fig. 3. Oxygen consumption plotted against wet weight for (a) Enypniastes eximia, (b) Bathocyroe fosteri, (c) unidentified ctenophore (UC-I), and (d) Benthocodon pedunculata. (•) In situ experiments; (o) shipboard runs. Geometric regressions $\left(Y=a X^{b}\right)$ are represented by solid and dashed lines for in situ and shipboard data, respectively

gelatinous zooplankton; (2) no significant effects of pressure (1 to $100 \mathrm{~atm}$ ) on the response of Nester electrodes; and (3) no significant differences in rates of oxygen decline in control chambers measured with the 2 probes on both cruises, we conclude that the observed differences in rates of respiration (in situ versus shipboard) were not due to differences in response characteristics of the 2 probe types.

\section{Excretion rates}

Variability in excretion values were substantially higher than those for oxygen consumption. Weight- specific rates of ammonia excretion were significantly higher for in situ incubations than shipboard rates for 3 species; Enypniastes eximia, Benthocodon pedunculata and UC-I ( $p<0.05, t$-test; Table 5). In situ and shipboard ammonia excretion rates for Bathocyroe fosteri were not statistically different, although the in situ rate was ca 1.7 times higher. The lack of statistical significance between ammonia excretion rates for $B$. fosteri was due primarily to the low $n$-value for shipboard experiments. Values for phosphate excretion were relatively low for both treatments.

Atomic ratios of oxygen respired to ammonium excreted (O:N) were generally twice as high for in situ samples as those incubated aboard ship (Table 6). The 

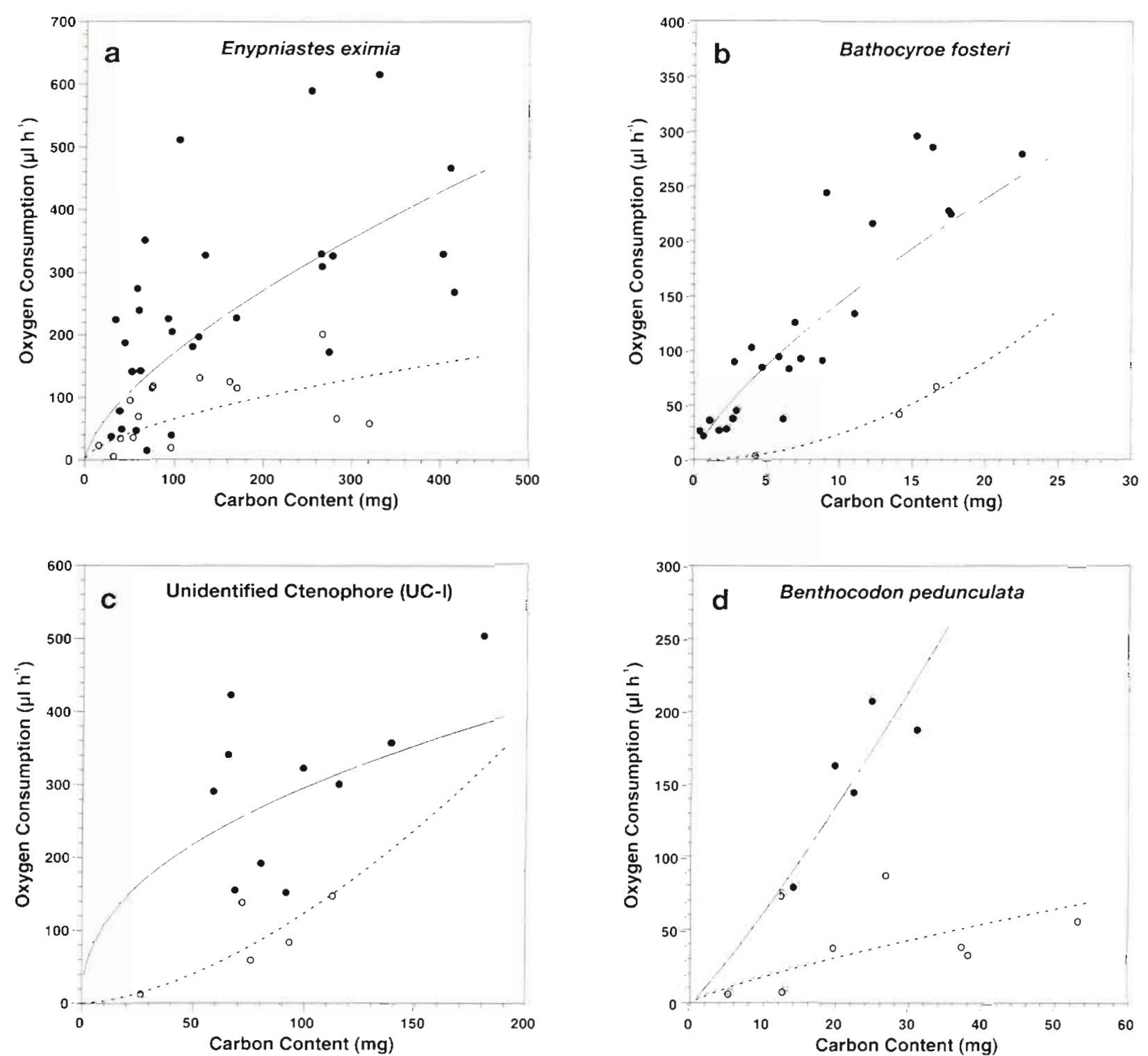

Fig. 4. Oxygen consumption plotted against carbon content for (a) Enypniastes eximia, (b) Bathocyroe fosteri, (c) unidentified ctenophore (UC-I), and (d) Benthocodon pedunculata. (•) In situ experiments; (0) shipboard runs. Geometric regressions $\left(Y=a X^{b}\right)$ are represented by solid and dashed lines for in situ and shipboard data, respectively

exception, UC-I, had a slightly lower in situ O:N ratio than that from the shipboard incubation. Atomic O:P ratios were relatively high, suggesting little physical damage to specimens (Ikeda et al. 1982)

\section{DISCUSSION}

\section{Comparisons with previous studies}

In situ oxygen consurnption rates of the 4 gelatinous species examined in this study were comparable to rates measured for gelatinous species in other studies (Table 7). For example, the in situ weight-specific rate of oxygen consumption for Enypniastes eximia was similar to that of the pelagic holothurian Scotoanassa sp. measured in the laboratory. However, the carbonspecific rate for Scotoanassa sp. was nearly 3 times higher than that of $E$ eximia. Differences in routine activity levels and concomitant compositional differences may account for the disparity in carbon-specific oxygen consumption rates of these 2 species. For example, E. eximia characteristically spends a substantial proportion of its time on the bottom, presumably feeding (Pawson 1982. Childress et al. 1989. Bailey \& Torres unpubl. data). Scotoanassa is rarely observed on the bottom, spending most of its time swimming in the water column (Barnes et al. 1976, 
Table 5. Mean dry weight- and carbon-specific ammonia and phosphate excretion rates measured in situ and in shipboard experiments. Numbers in parentheses are standard deviation (SD) and number of individuals (n) analyzed

\begin{tabular}{|c|c|c|c|c|c|c|c|c|}
\hline \multirow{2}{*}{ Species } & \multicolumn{4}{|c|}{ In situ } & \multicolumn{4}{|c|}{ Shipboard } \\
\hline & $\begin{array}{c}\mathrm{NH}_{4} \\
\left(\mu \mathrm{M} \mathrm{g}^{-1} \mathrm{DWh}^{-1}\right)\end{array}$ & $\underset{\mathrm{NH}_{4}}{\left(\mu \mathrm{Mg}^{-1} \mathrm{C} n\right.}$ & $\begin{array}{c}\mathrm{PO}_{4} \\
\left.\mu \mathrm{M} \mathrm{g}^{-3} \mathrm{DW} \mathrm{h}^{-1}\right)\end{array}$ & $\begin{array}{c}\mathrm{PO}_{4} \\
\left(\mu \mathrm{M} \mathrm{g}^{-1} \mathrm{Ch}^{-1}\right)\end{array}$ & $\begin{array}{c}\mathrm{NH}_{4} \\
\left\{\mu \mathrm{M} \mathrm{g}^{-1} \mathrm{DWh}^{-1}\right)\end{array}$ & $\begin{array}{c}\mathrm{NH}_{4} \\
\left(\mu \mathrm{Mg} \mathrm{g}^{-1} \mathrm{Ch}^{-1}\right)\end{array}$ & $\begin{array}{c}\mathrm{PO}_{4} \\
\left(\mu \mathrm{Mg}^{-1} \mathrm{DWh} \mathrm{h}^{-1}\right)\end{array}$ & $\begin{array}{c}\mathrm{PO}_{4} \\
\left(\mu \mathrm{Mg}^{-1} \mathrm{Ch}^{-1}\right)\end{array}$ \\
\hline $\begin{array}{l}\text { Enypniastes } \\
\text { eximia }\end{array}$ & $\begin{array}{c}0.131 \\
( \pm 0.739,30)\end{array}$ & $\begin{array}{c}13.071 \\
( \pm 14.332,30)\end{array}$ & $\begin{array}{c}0.023 \\
( \pm 0.106,18)\end{array}$ & $\begin{array}{c}2.457 \\
( \pm 2.798,18)\end{array}$ & $\begin{array}{c}0.072 \\
( \pm 0.097,15)\end{array}$ & $\begin{array}{c}7.832 \\
( \pm 4.100,15)\end{array}$ & $\begin{array}{c}0.004 \\
\pm 0.007,13)\end{array}$ & $\begin{array}{c}0.373 \\
\pm 0.258,13)\end{array}$ \\
\hline $\begin{array}{l}\text { Bathocyroe } \\
\text { fosteri }\end{array}$ & $\begin{array}{c}0.514 \\
( \pm 1.671,24\}\end{array}$ & $\begin{array}{c}99.253 \\
( \pm 46.818,24)\end{array}$ & $\begin{array}{c}0.126 \\
\pm 1.395,20\}\end{array}$ & $\begin{array}{c}14.306 \\
\pm 16.583,20\}\end{array}$ & $\begin{array}{c}0.310 \\
( \pm 0.511,3)\end{array}$ & $\begin{array}{c}63.890 \\
( \pm 48.191,3)\end{array}$ & $\begin{array}{c}0.013 \\
( \pm 0.021,3)\end{array}$ & $\begin{array}{c}2.705 \\
( \pm 2.045,3)\end{array}$ \\
\hline UC-I & $\begin{array}{c}0.106 \\
( \pm 0.196,11)\end{array}$ & $\begin{array}{c}23.200 \\
( \pm 17.248,11)\end{array}$ & $\begin{array}{c}0.008 \\
( \pm 0.023,11)\end{array}$ & $\begin{array}{c}1.751 \\
( \pm 1.710,11)\end{array}$ & $\begin{array}{c}0.019 \\
\pm 0.018,5)\end{array}$ & $\begin{array}{l}3.961 \\
( \pm 1.599,5)\end{array}$ & $\begin{array}{c}0.010 \\
( \pm 0.011,5)\end{array}$ & $\begin{aligned} & 2.208 \\
&( \pm 1.087,5)\end{aligned}$ \\
\hline $\begin{array}{l}\text { Benthocodon } \\
\text { pedunculata }\end{array}$ & $\begin{array}{c}3.274 \\
( \pm 3.019,5)\end{array}$ & $\begin{array}{c}47.256 \\
( \pm 14.145,5)\end{array}$ & $\begin{array}{c}0.547 \\
\pm 0.648,5)\end{array}$ & $\begin{array}{c}6.543 \\
( \pm 3.196,5)\end{array}$ & $\begin{array}{c}1.788 \\
( \pm 1.813,8)\end{array}$ & $\begin{array}{c}20.414 \\
( \pm 13.534,8)\end{array}$ & $\begin{array}{c}0.216 \\
( \pm 0.520,8)\end{array}$ & $\begin{array}{c}2.515 \\
( \pm 2.822,8)\end{array}$ \\
\hline
\end{tabular}

Pawson 1982, Childress et al. 1989). Consequently, a higher metabolic rate would be expected from $\mathrm{Sco}$ toanassa, since it appears to be more active. Differences in buoyancy of the 2 species may also contribute to the observed similarities in weight-specific metabolic rates. Assuming that in situ rates of metabolism for Scotoanassa are somewhat higher than those measured in the laboratory (Childress et al. 1989), the slight difference in weight-specific metabolic rates of the two holothurians would be somewhat greater than that shown in Table 7 .

Both in situ and shipboard rates of weight-specific oxygen consumption for Bathocyroe fosteri were substantially different from published rates (Table 7; Youngbluth et al. 1988). In situ rates were higher by a factor of 2 and shipboard rates of oxygen consumption were lower by a factor of 3.5 than the shipboard values reported by Youngbluth et al. (1988). Handling techniques, as well as seasonal variability may account for some of these differences. The in situ rate of weightspecific oxygen consumption for $B$. fosteri was within the range of values measured for epipelagic ctenophore species (Table 7). Because of its low carbon con- tent, the in situ carbon-specific oxygen consumption for B. fosteri was substantially higher than values published for both epipelagic and mesopelagic ctenophores (Table 7). Values for the unidentified lobate UC-I were substantially lower than those of the lobate ctenophores B. fosteri and Ocyropsis sp. (Youngbluth et al. 1988). The lower rate cannot be explained on the basis of differences in water or organic content, since all 3 ctenophore species have nearly the same percentages of water and carbon in their tissues (Table 3; Youngbluth et al. 1988).

The in situ weight-specific oxygen consumption rate for the trachymedusa Benthocodon pedunculata was significantly higher than those of any other midwater medusa, and generally higher than most epipelagic species (Table 7 ). This higher rate might be expected since $B$. pedunculata is a very robust benthopelagic jellyfish with high levels of body carbon and nitrogen (Table 3). Swimming bursts for B. pedunculata ranged from 0.1 to $0.2 \mathrm{kt}$ (Bailey pers. obs.). However, because of its high carbon content, the carbon-specific rate of oxygen consumption for $B$, pedunculata, although greater than most epipelagic species, was not substan-

Table 6. O:N and O:P ratios (atoms of oxygen consumed to atoms of nitrogen and phosphorus excreted). Numbers in parentheses are the standard deviation (SD) and number of individuals (n) analyzed

\begin{tabular}{|lcccc|}
\hline Species & \multicolumn{2}{c}{ In situ } & \multicolumn{2}{c|}{ Shipboard } \\
\hline Enypniastes eximia & O:N & O:P & O:N & O:P \\
Bathocyroe fosteri & 19.31 & 181.11 & 10.19 & 232.38 \\
& $( \pm 10.67,30)$ & $( \pm 180.84,18)$ & $( \pm 4.72,15)$ & $( \pm 184.84,13)$ \\
UC-I & 17.80 & 290.80 & 9.04 & 316.83 \\
& $( \pm 11.28,24)$ & $( \pm 229.56,20)$ & $( \pm 0.68,3)$ & $( \pm 266.33,3)$ \\
Benthocodon pedunculata & 17.47 & 253.11 & 24.51 & 50.23 \\
& $( \pm 9.32,11)$ & $( \pm 118.87,11)$ & $( \pm 7.61,5)$ & $( \pm 28.60,5)$ \\
& $( \pm 7.52,5)$ & $( \pm 62.04,5)$ & $( \pm 5.73,8)$ & $( \pm 134.77,8)$ \\
\hline
\end{tabular}


Table 7. Comparison of oxygen consumption values for gelatinous and non-gelatinous zooplankton and micronekton. Mes/Epi: normal depth of occurrence (mesopelagic or epipelagic). n: number of individuals analyzed. Temperatures are those at which incubations were conducted. a Species measured in situ; ${ }^{b}$ carbon-specific values estimated based on the assumption that carbon content (C) was equal to 8 to $10 \%$ of the wet weight (WW); 'Carbon-specific values estimated based on a carbon content of $0.6 \%$ of the dry weight

\begin{tabular}{|c|c|c|c|c|c|c|}
\hline \multirow{2}{*}{ Species } & \multirow[t]{2}{*}{ Mes/Epi } & \multirow[t]{2}{*}{$\mathrm{n}$} & \multirow{2}{*}{$\begin{array}{c}\mathrm{T} \\
\left({ }^{\circ} \mathrm{C}\right)\end{array}$} & \multicolumn{2}{|c|}{ Oxygen consumption } & \multirow[t]{2}{*}{ Source } \\
\hline & & & & $\mu l \mathrm{O}_{2} g^{-1} W W h^{-1}$ & $\mu \mathrm{l} \mathrm{O}_{2} \mathrm{mg}^{-1} \mathrm{C} \mathrm{h}^{-1}$ & \\
\hline \multicolumn{7}{|l|}{ GELATINOUS SPECIES } \\
\hline \multicolumn{7}{|l|}{ Holothurians } \\
\hline Enypniastes eximia ${ }^{a}$ & Mes & 31 & 8 & 0.814 & 4.013 & 1 \\
\hline Enypniastes eximia & Mes & 15 & 8 & 0.307 & 0.746 & 1 \\
\hline Scotoanassa sp. & Mes & 15 & 3 & 0.9 & 11.110 & 2 \\
\hline \multicolumn{7}{|l|}{ Ctenophores } \\
\hline Bathocyroe fosteri & Mes & 24 & 8 & 3.057 & 19.157 & 1 \\
\hline Bathocyroe fosteri & Mes & 3 & 8 & 0.456 & 6.601 & 1 \\
\hline Bathocyroe fosteri & Mes & 49 & $9-12$ & 1.596 & 5.122 & 3 \\
\hline$U C-I^{a}$ & Mes & 11 & 8 & 0.629 & 3.373 & 1 \\
\hline UC-I & Mes & 5 & 8 & 0.191 & 1.080 & 1 \\
\hline Ocyropsis sp. & Mes & 6 & $9-12$ & 4.787 & 6.300 & 3 \\
\hline Agmayeria tortugensis & Mes & 1 & 8 & 2.264 & 0.673 & 1 \\
\hline Bolinopsis infundibulum & Mes & 10 & $5-6$ & 2.052 & 2.477 & 4 \\
\hline Bolinopsis infundibulum & Epi & 8 & 8 & 1.254 & 1.740 & 5 \\
\hline Bolinopsis vitrea & Epi & 55 & 25 & 2.660 & 11.670 & 6 \\
\hline Ocyropsis maculata & Epi & 3 & 25 & 4.800 & 0.529 & 6 \\
\hline Eurhamphaea vexilligera & Epi & 47 & $25-29$ & 2.520 & 7.160 & 7 \\
\hline Mnemiopsis mccradyi & Epi & 22 & 21 & 3.332 & 5.160 & 8 \\
\hline Mnemiopsis leidyi & Epi & 19 & 10 & 2.380 & 4.120 & 9 \\
\hline Mnemiopsis leidyi & Epi & 21 & 25 & 7.854 & 13.590 & 9 \\
\hline Beroe ovata & Epi & 22 & 25 & 10.920 & 7.340 & 6 \\
\hline \multicolumn{7}{|l|}{ Medusae } \\
\hline Benthocodon pedunculata ${ }^{a}$ & Mes & 5 & 8 & 26.639 & 6.928 & 1 \\
\hline Benthocodon pedunculata & Mes & 9 & 8 & 8.461 & 1.818 & 1 \\
\hline Solmissus sp..$^{2}$ & Mes & 4 & 8 & 4.502 & 7.870 & 1 \\
\hline Poralia rufescens ${ }^{a}$ & Mes & 2 & 3 & 6 & $26.345^{b}$ & 10 \\
\hline Crossota rufobrunnea & Mes & 12 & 5 & 3.6 & 0.900 & 11 \\
\hline Aegina citrea & Mes & 8 & 5 & 2.8 & 0.700 & 11 \\
\hline Aequorea victoria & Epi & 45 & 10 & 3.9 & 1.100 & 12 \\
\hline Aglantha digitale & Epi & 22 & 10 & 43.7 & 5.810 & 12 \\
\hline Eperetmus typus & Epi & 11 & 10 & 10.0 & 2.910 & 12 \\
\hline Eutonina indicans & Epi & 25 & 10 & 10.6 & 3.150 & 12 \\
\hline Gonionemus vertens & Epi & 12 & 10 & 26.7 & 4.230 & 12 \\
\hline Mitrocoma cellularia & Epi & 32 & 10 & 3.2 & 3.210 & 12 \\
\hline Phialidium gregarium & Epi & 24 & 10 & 10.1 & 2.770 & 12 \\
\hline Sarsia princeps & Epi & 8 & 10 & 6.1 & 2.390 & 12 \\
\hline Stomotoca atra & Epi & 14 & 10 & 11.2 & 2.710 & 12 \\
\hline Aurelia aurita & Epi & 18 & 10 & 5.3 & 3.260 & 12 \\
\hline Cyanea capillata & Epi & 16 & 10 & 20.2 & 3.750 & 12 \\
\hline \multicolumn{7}{|l|}{ CRUSTACEANS } \\
\hline Thysanopoda monocantha & Mes & 7 & 7 & 86 & $0.873^{c}$ & 13 \\
\hline Sergestes armatus & Mes & 3 & 7 & 85 & 0.750 & 13 \\
\hline Sergestes corniculum & Mes & 3 & 7 & 90 & 0.730 & 13 \\
\hline Sergia grandis & Mes & 3 & 14 & 159 & 1.520 & 13 \\
\hline Gnathophausia ingens & Mes & 41 & 5.5 & 54.4 & 0.404 & 14 \\
\hline Boreomysis californica & Mes & 6 & 5.5 & 29.4 & 0.389 & 14 \\
\hline Acanthephyra curtirostris & Mes & 9 & 5.5 & 36.3 & 0.351 & 14 \\
\hline Systellaspis cristata & Mes & 4 & 5.5 & 32.9 & 0.239 & 14 \\
\hline Hymenodora frontalis & Mes & 4 & 5.5 & 23.3 & 0.127 & 14 \\
\hline Pasiphaea emarginata & Mes & 6 & 5.5 & 20.6 & 0.195 & 1.4 \\
\hline Gigantocypris agassizii & Mes & 2 & 4 & 1.5 & 0.311 & 14 \\
\hline Bathycalanus bradyi & Mes & 5 & 4 & 39.1 & $0.331^{c}$ & 14 \\
\hline
\end{tabular}


Table 7 (continued)

\begin{tabular}{|c|c|c|c|c|c|c|}
\hline \multirow[t]{2}{*}{ Species } & \multirow[t]{2}{*}{ Mes/Epi } & \multirow[t]{2}{*}{$\mathrm{n}$} & \multirow{2}{*}{$\begin{array}{c}\mathrm{T} \\
\left({ }^{\circ} \mathrm{C}\right)\end{array}$} & \multicolumn{2}{|c|}{ Oxygen consumption } & \multirow[t]{2}{*}{ Source } \\
\hline & & & & $\mu] \mathrm{O}_{2} \mathrm{~g}^{-1} \mathrm{WW} \mathrm{h}^{-i}$ & $\mu \mathrm{l} \mathrm{O}_{2} \mathrm{mg}^{-1} \mathrm{Ch}^{-1}$ & \\
\hline \multicolumn{7}{|l|}{ FISHES } \\
\hline Coryphaenoides acrolepis ${ }^{\mathrm{a}}$ & Mes & 1 & 3.5 & 2.4 & $0.030^{\ulcorner}$ & 15 \\
\hline Coryphaenoides armatus ${ }^{\text {a }}$ & Mes & 3 & 3.0 & 3.2 & $0.040^{\circ}$ & 16 \\
\hline Eptatretus deania & Mes & 1 & 3.5 & 2.2 & $0.028^{\circ}$ & 15 \\
\hline Sebastolobus altivelis (juv) ${ }^{a}$ & Mes & 2 & 5.7 & 30.5 & $0.383^{c}$ & 17 \\
\hline S. altivelis (adult) & Mes & 4 & 5.7 & 2.8 & $0.035^{c}$ & 17 \\
\hline Cyclothone acclinidens ${ }^{\mathrm{d}}$ & Mes & 3 & 3 & 25 & $0.287^{\circ}$ & 18 \\
\hline Gonostoma elongatum & Mes & 7 & 7 & 39.0 & $1.300^{c}$ & 13 \\
\hline Melanostigma pammelas & Mes & 2 & 5.5 & 16.1 & $0.124^{\mathrm{c}}$ & 14 \\
\hline Nectoliparis pelagicus & Mes & 3 & 5.5 & 42.7 & $0.534^{c}$ & 14 \\
\hline Bajacalifornia burragei & Mes & 3 & 5 & 5 & $0.113^{c}$ & 19 \\
\hline Bathylagus milleri & Mes & 3 & 5 & 11 & $0.213^{c}$ & 19 \\
\hline Melamphaes acanthomus & Mes & 4 & 5 & 12 & $0.256^{c}$ & 19 \\
\hline Poromitra crassiceps & Mes & 2 & 5 & 11 & 0.220 & 19 \\
\hline Melanonus zugmayeri & Mes & 4 & 5 & 17 & $0.213^{c}$ & 19 \\
\hline Lampanyctus regalis & Mes & 1 & 5 & 11 & 0.179 & 19 \\
\hline Parvilux ingens & Mes & 3 & 5 & 12 & $0.333^{c}$ & 19 \\
\hline Scopelengys tristis & Mes & 2 & 5 & 9 & 0.106 & 19 \\
\hline Oneirodes acanthias & Mes & 2 & 5 & 8 & 0.207 & 19 \\
\hline
\end{tabular}

tially different from that of the very diaphanous midwater medusa, Solmissus sp. (Table 7). The very high value for carbon-specific respiration of Poralia rufescens in Table 7 is primarily due to our use of low carbon values measured on 12 large individuals sampled off Cape Hatteras, North Carolina, USA (Bailey unpubl. data).

Excretion data for mesopelagic gelatinous animals are sparse and shallow-living species show a large range of variability. Nevertheless, ammonia excretion rates and $\mathrm{O}: \mathrm{N}$ ratios for all 4 species are in general agreement with those reported for epipelagic and mesopelagic gelatinous animals (Kremer 1975, 1977, Biggs 1977, Smith 1982, Cetta et al. 1986, Kremer et al. 1986, Youngbluth et al. 1988). O:N ratios were consistent with a protein-based metabolism (Ikeda 1974). Assuming that organic nitrogen is also released by these species, $\mathrm{O}: \mathrm{N}$ values would be reduced to levels approaching the ideal protein catabolism of 8 (Ikeda 1974). Lower rates of excretion in shipboard experiments may reflect changes in the same physiological processes responsible for differences in oxygen consumption rates (e.g. pressure effects on membrane lipids; see subsequent section).

Because of differences in methods of capture, handling and analysis, caution must be exercised in comparing literature values for metabolic rates of gelatinous animals. However, the similarity of our in situ rates of oxygen consumption with both in situ and laboratory rates for mesopelagic and epipelagic species support the theory that, after accounting for differences in temperature, the metabolic rates of deep-living gelatinous zooplankton are not substantially different from those of epipelagic species (cf. Childress \& Thuesen 1992). The absence of a metabolic decline with depth of occurrence, as seen in crustaceans and fishes (e.g. Childress 1975, Torres et al. 1979), suggests that deep-living gelatinous zooplankton may be more important to deep-sea carbon cycling than previously thought. For example, although weight-specific metabolism of deep-living gelatinous species is substantially lower than those of most midwater crustaceans and fishes, their carbon-specific rates are substantially higher (Table 7 ).

\section{Comparison of in situ and shipboard metabolic rates}

Metabolism of individuals incubated in situ was uniformly higher than that of individuals brought to the surface and incubated in the shipboard laboratory. Differences varied from nearly 3 -fold for Enypniastes eximia to nearly 7 -fold for Bathocyroe fosteri, with UC-I (ca 3-fold) and Benthocodon pedunculata (ca 3 -fold) closer to the low end of the range. These substantial differences in metabolism fall within the range that can be accounted for by differences in activity level of individuals in the 2 treatments (see Childress 
1975, Torres et al. 1979, Donnelly \& Torres 1988 and Torres \& Somero 1988 for range of metabolic fluctuation in crustaceans and fishes), provided that the scope for metabolism (Brett \& Groves 1979) in the 4 species of gelatinous zooplankton examined is similar to that of other swimming species. This seems likely, since those invertebrates and fishes that have been examined are capable of modulating their oxygen consumption rate by a factor of 3 to 6 (cf. Tucker 1970, Schmidt-Neilsen 1972, Beamish 1978, O'Dor 1982, Torres 1984). What remains to be explained is why activity is consistently higher in the respirometers at depth, since the individuals brought to the surface, though treated in as gentle and unobtrusive a manner as current technology will allow, still received more stimulation than their counterparts at depth and thus would be expected to show the higher metabolic rates. Since the single largest difference between treatments was that individuals incubated in situ were maintained at an ambient pressure of 68 to $75 \mathrm{~atm}$ and those in the lab were incubated at 1 atm, we concluded that the disparity in activity level was most simply explained by an interaction between pressure and activity, specifically, a loss of motor activity due to decompression in those individuals measured on board ship.

Although few investigations have been conducted into adaptive differences in physiological and biochemical systems of shallow and deep-living organisms, the majority of deep-living pelagic species appear to be either insensitive to the hydrostatic pressures encountered within their vertical range (cf. Teal 1971, Smith \& Teal 1973, Belman \& Gordon 1979, Torres \& Childress 1983, Somero 1991, Childress \& Thuesen 1993) or show slight acceleratory effects due to pressure (Teal 1971, George 1981). On the other hand, benthic and benthopelagic species with lower likelihood for large vertical excursions, particularly in the time frame of days to weeks, can exhibit pronounced behavioral or physiological responses to decompression, ranging from depleted locomotory abilities to a slowdown in heart rate. Such responses to decompression have been observed in benthic amphipods (Yayanos 1978, Macdonald \& Gilchrist 1982), cottid fishes (Brauer et al. 1984) and the hydrothermal vent crab Bythograea thermydron (Mickel \& Childress 1982a). In each of those studies the negative effects of decompression were reversed by recompression to in situ pressures (see Somero 1991, 1992 for reviews).

The primary effects of pressure on biological systems are related to changes in volume associated with physiological and biochemical processes. Sublethal pressure effects on metabolism mainly reside in the influence of pressure on membrane structure and function (e.g. binding of ligands, such as hormones and transmitters) and are manifested most strongly in neuromuscular activity (Somero 1991). For example, decompression of deep-living marine and freshwater species can lead to symptoms resembling those of high pressure neurological syndrome (HPNS) experienced by shallow-living species at high pressure (Meek \& Childress 1973, Brauer et al. 1980, Macdonald \& Gilchrist 1982). These findings suggest that neural membranes are adapted to function over a relatively narrow range of pressures, and that pressures outside of that range will adversely affect neural activity. Few studies of the effects of pressure on neural functions have been done with deep-living organisms. However, the limited data available indicate that pronounced adaptation of neural function to pressure is characteristic of deep-sea invertebrates (Campenot 1975) and fishes (Harper et al. 1987). The barophilic nature of neurological function for 2 species of deep-sea fishes was demonstrated by the finding that nerves of moribund fish could be restored to apparent normal function after incubation at the species' ambient pressures (Harper et al. 1987). Likewise, the hydrothermal vent crab Bythograea thermydron showed a disruption of the electrocardiogram, a loss of muscular coordination, and abnormally low rates of oxygen consumption after decompression (Mickel \& Childress 1982b). These results suggest that at least some deep-sea animals may be obligate barophiles, requiring high pressure for survival.

Species with limited vertical ranges are afforded the luxury of adjusting membrane structure (homeoviscous adaptation) to allow normal neuromuscular function in a fairly narrow temperature-pressure window and thus are most sensitive to hydrostatic pressure, or to decompression. Hydrostatic pressure could potentially affect membrane proteins, the lipid bilayer, or both. Lipid bilayer viscosity is a likely candidate for adaptive regulation in deep-living species because of the strong interacting effects of high pressure and low temperature on physical properties of lipids. Perturbations in pressure or temperature that affect the viscosity of membrane lipids will thus affect membranebased physiological and biochemical processes. Homeoviscous pressure acclimations could be of particular importance in deep-sea animals with shallowliving larvae and juveniles. However, studies of homeoviscous acclimation to pressure have not been done with metazoans.

Along with the pressure sensitivity of membranebased processes, recent studies have shown that pressure sensitivities of enzymes and structural proteins differ markedly between shallow- and deep-living species (e.g. Swezey \& Somero 1982, 1985, Hennessey \& Siebenaller 1985, 1987, Siebenaller 1987). These comparative studies provide operational definitions of what constitutes high pressures for different biological 
structures and processes. The delineation of adaptation pressures at which a given type of system exhibits perturbation by pressure suggests that the terms deep and high pressure begin to apply at depths of only $500 \mathrm{~m}$ or less (Somero 1992). Furthermore, because of the paucity of data on the effects of reduced pressure on the physiology of deep-living species, processes yet to be examined in comparative analyses may yield even lower pressure thresholds.

\section{CONCLUSIONS}

All of the individuals examined in the present study had 2 characteristics in common. The first is that they were all captured within $50 \mathrm{~m}$ of the bottom at depths between 735 and $900 \mathrm{~m}$. The second was that all of the species were quite fragile. None of them could be taken with a net and be expected to remain intact. In fact, only Benthocodon pedunculata and Enypniastes eximia could be manipulated at all after capture. The other species were so delicate that attempts at transfer often caused them to break apart. Their diaphanous character may be the underlying reason for the species' metabolic response to decompression. Whether due to the limited depth range of the species within the study area or their delicate character, the data strongly suggest that an effect of decompression occurs.

All deep-living pelagic species that have been previously examined for responses to pressure, whether they were crustaceans, molluscans, fishes, hydromedusans, or chaetognaths (Smith 1982, Somero 1991, Childress \& Thuesen 1993), have been robust enough to be captured intact in a net or suction sampler before experimental manipulation. The delicate structure of the gelatinous animals examined in our study apparently confers upon them a degree of pressure-dependence that has not been observed previously.

Our results suggest that even the most delicate gelatinous zooplankton can be important contributors to carbon flow at depth (cf. Childress \& Thuesen 1992, 1993). The observed effects of decompression on delicate forms can lead to serious underestimation of their in situ metabolic rates and thus, models that require such data would underestimate the relative roles of mesopelagic gelatinous zooplankton in carbon cycling in the deep sea.

Acknowledgements. We are grateful to the captains and crews of the RV 'Edwin Link', RV 'Seward Johnson' and Johnson-Sea-Link submersibles for their assistance at sea. We thank the graduate students from the Department of Marine Sciences, University of South Florida who participated in our 2 cruises, especially Shana Smith, who conducted the ammonia and phosphate analyses at sea. This work constitutes con- tribution No. 1053 of the Harbor Branch Oceanographic Institution, and was supported in part by Grants from the National Science Foundation (OCE-9012436) and The Link Foundation.

\section{LITERATURE CITED}

Bailey, T. G., Youngbluth, M. J., Owen, G. P. (1994). Chemical composition and oxygen consumption rates of the ctenophore Bolinopsis infundibulum from the Gulf of Maine. J. Plankton Res. 16:673-689

Barnes, A. T., Quetin, L. B., Childress, J. J., Pawson, D. L. (1976). Deep-sea macroplanktonic sea cucumbers: suspended sediment feeders captured from deep submergence vehicle. Science 194: 1083-1085

Baumgärtl, H., Lübbers, D. W. (1983). Microaxial needle sensor for polarographic measurement of local $\mathrm{O}_{2}$ pressure in the cellular range of living tissue. Its construction and properties. In: Gnaiger, E., Forstner, H. (eds.) Polarographic oxygen sensors. Springer-Verlag, Berlin, p. 37-65

Beamish, F. W. H. (1978). Swimming capacity. In: Hoar, W. S. Randall, D. J. (eds.) Fish physiology, Vol. 7. Academic Press, New York, p. 101-187

Belman, B., Gordon, M. S. (1979). Comparative studies on the metabolism of shallow-water and deep-sea marine fishes. 5. Effects of temperature and hydrostatic pressure on oxygen consumption in the mesopelagic zoarcid Melanostigma pammelas. Mar. Biol. 50: 275-281

Biggs, D. C. (1977). Respiration and ammonium excretion by open ocean gelatinous zooplankton. Limnol. Oceanogr. 22: $108-118$

Billett, D. S. M. (1986). The rise and rise of the sea cucumber New Scientist 109: 48-51

Billett, D. S. M., Hansen, B., Huggett, Q. J. (1985). Pelagic Holothurioidea of the northeast Atlantic. In: Kegan, B. F. O'Connor, B. D. S. (eds.) Echinodermata. Balkema, Rotterdam, p. 399-411

Brauer, R. W., Bekman, M. Y., Keyser, J. B., Nesbitt, D. L., Sidelov, G. N., Wright, S. L. (1980). Adaptation to high hydrostatic pressure of abyssal gammarids from Lake Baikal in eastern Siberia. Comp. Biochem. Physiol. 65A: 109-117

Brauer, R. W., Sidelyova, V. G., Dail, M. B., Galazii, G. I., Roer, R. D. (1984). Physiological adaptation of cottoid fishes of Lake Baikal to abyssal depths. Comp. Biochem. Physiol. 77: 699-705

Brett, J. R., Groves, T. D. D. (1979). Physiological energetics. In: Hoar, W. S., Randall, D. J. (eds.) Fish physiology, Vol. 8. Academic Press, New York, p. 279-352

Campenot, R. B. (1975). The effects of high hydrostatic pressure on transmission at the crustacean neuromuscular junction. Comp. Biochem. Physiol. 52: 133-140

Cetta, C. M., Madin, L. P., Kremer, P. (1986). Respiration and excretion by oceanic salps. Mar. Biol. 91: 529-537

Childress, J. J. (1975). Respiratory rate of mid-water crustaceans as a function of depth of occurrence and the relation to the oxygen minimum layer off Southern California. Comp. Biochem. Physiol. 50A: 787-799

Childress, J. J., Gluck, D. L., Camey, R. S., Gowing, M. M. (1989). Benthopelagic biomass distribution and oxygen consumption in a deep-sea benthic boundary layer dominated by gelatinous organisms. Limnol. Oceanogr. 34: 913-930

Childress, J. J., Thuesen, E. V. (1992). Metabolic potential of deep-sea animals: regional and global scales. In: Rowe, G., Pariente, V. (eds.) Deep-sea food chains and the global carbon cycle. Kluwer, New York, p. 217-236 
Childress, J. J., Thuesen, E. V (1993). Effects of hydrostatic pressure on metabolic rates of six species of deep-sea gelatinous zooplankton. Limnol. Oceanogr. 38: 665-670

Donnelly, J., Torres, J. J. (1988). Oxygen consumption of midwater fishes and crustaceans from the eastern Gulf of Mexico. Mar. Biol. 97: 483-494

George, R. Y (1981). Functional adaptations of deep-sea organisms. In: Vernberg, F. J., Vernberg, W. B. (eds.) Functional adaptations of marine organisms. Academic Press, New York, p. 279-332

Gyllenberg, G., Greve, W. (1979). Studies on oxygen uptake in ctenophores. Ann. zool. fenn. 16: 44-49

Harper, A. A., Macdonald, A. G., Wardle, C. S., Pennec, J.-P. (1987). The pressure tolerance of deep-sea fish axons: results of Challenger cruise 6B/85. Comp. Biochem. Physiol 88A: $647-653$

Hennessey, J. P. Jr, Siebenaller, J. F. (1985). Pressure inactivation of tetrameric lactate dehydrogenase homologues of confamilial deep-living fishes. J. comp. Physiol. B 155 $647-652$

Hennessey, J. P. Jr, Siebenaller, J. F. (1987). Pressure-adaptive differences in proteolytic inactivation of $\mathrm{M}_{4}$-lactate dehydrogenase homologues from marine fishes. J. exp. Zool 241. $9-15$

Hoeger, U. (1983). Biochemical composition of ctenophores J. exp. mar. Biol. Ecol. 72: 251-261

Ikeda, T. (1974). Nutritional ecology of marine zooplankton. Mem. Fac. Fish. Hokkaido Univ. 22: 1-97

Ikeda, T., Hing Fay, E., Hutchinson, S. A., Boto, G. M. (1982) Ammonia and inorganic phosphate excretion by zooplankton from inshore waters of the Great Barrier Reef Queensland. I. Relationship between excretion rates and body size. Aust. J. mar. Freshwat. Res. 33: 55-70

Kremer, P. (1975). Excretion and body composition of the ctenophore Mnemiopsis leidyi (A. Agassiz): comparisons and consequences. In: Persoone, G., Jaspers, F. (eds.) Proc. 10th Eur. mar. Biol. Symp, Vol. 2. Universa Press, Wetteren, p. 351-362

Kremer, P. (1977). Respiration and excretion by the ctenophore Mnemiopsis leidyi. Mar. Biol. 44: 43-50

Kremer, P. (1982). Effect of food availability on the metabolism of the ctenophore Mnemiopsis mccradyi. Mar. Biol. 71. 149-156

Kremer, P., Canino, M. F., Gilmer, R. W. (1986). Metabolism of epipelagic tropical ctenophores. Mar. Biol. 90: 403-412

Kremer, P., Madin, L. P., Purcell, J. E., Nemazie, D. A. (1994). Ecological consequences of a salp swarm: particulate ingestion, transformation, and vertical transport. EOS 75 187

Larson, R. J. (1987). Respiration and carbon turnover rates of medusae from the NE Pacific. Comp. Biochem. Physiol. $87 \mathrm{~A}: 93-100$

Larson, R. J., Matsumoto, G. I., Madin, L. P., Lewis, L. M (1992). Deep-sea benthic and benthopelagic medusae: recent observations from submersibles and a remotely operated vehicle. Bull. mar. Sci. 5: 277-286

Macdonald, A. G., Gilchrist, I. (1982). The pressure tolerance of deep-sea amphipods collected at their ambient high pressure Comp. Biochem. Physiol. 71A: 349-352

Madin, L. P., Harbison, G. R. (1978). Bathocyroe fosteri, gen. nov., sp. nov.: a mesopelagic ctenophore observed and collected from a submersible. J. mar. biol. Ass. U.K. 58: $559-564$

Madin, L. P., Kremer, P., Purcell, J. E., Nemazie, D. A. (1994). Vertical migration of a large Salpa aspera population in the north Atlantic slope water. EOS 75: 90

Meek, R. P., Childress, J. J. (1973). Respiration and the effect of pressure in the mesopelagic fish Anoplogaster cornuta (Beryciformes). Deep Sea Res. 29: 1111-1118

Mickel, T. J., Childress, J. J. (1982a). Effects of pressure and temperature on the EKG and heart rate of the hydrothermal vent crab Bythograed thermydron (Brachyura) Biol. Bull. Woods Hole 162: 70-82

Mickel, T. J., Childress, J. J. (1982b). Effects of temperature, pressure and oxygen concentration on the oxygen consumption rate of the hydrothermal vent crab Bythograea thermydron (Brachyura). Physiol. Zool. 55: 199-207

Mickel, T. J., Quetin, L. B., Childress, J. J. (1983). Construction of a polarographic oxygen sensor in the laboratory. In: Gnaiger, E., Forstner, H. (eds.) Polarographic oxygen sensors: aquatic and physiological applications. SpringerVerlag, New York, p. 81-85

Miller, J. E., Pawson, D. L. (1990). Swimming sea cucumbers (Echinodermata: Holothuroidea): a survey, with analysis of swimming behavior in four bathyal species. Smithson. Contr. mar. Sci. 35: 1-18

O'Dor, R. D. (1982). Respiratory metabolism and swimming performance of the squid Loligo opalescens. Can. J. Fish. Aquat. Sci. 39: 580-587

Pawson, D. L. (1982). Deep-sea echinoderms in the Tongue of the Ocean, Bahama Islands: a survey using the research submersible 'Alvin'. Mem. Aust. Mus. 16: 129-145

Reeve, M. R., Baker, L. D. (1975). Production of two planktonic carnivores (chaetognath and ctenophore) in South Florida inshore waters. Fish. Bull. U.S. 73: 238-248

Reeve, M. R., Walter, M. A., Ikeda, T. (1978). Laboratory studies of ingestion and food utilization in lobate and tentaculate ctenophores. Limnol. Oceanogr. 23: 740-751

Robison, B. H. (1992). Bioluminescence in the benthopelagic holothurian Enypniastes eximia. J. mar. biol. Ass. U.K. 72 $463-472$

Schmidt-Nielsen, K. (1972). Locomotion: energy cost of swimming, flying and running. Science 177: 222-228

Siebenaller, J. F. (1987). Pressure adaptation in deep-sea animals. In: Jannasch, H. W., Marquis, R. E., Zimmerman, A. M. (eds.) Current perspectives in high pressure biology. Academic Press, London, p. 33-48

Smith, K. L. Jr (1978). Metabolism of the abyssopelagic rattail Coryphaenoides armatus measured in situ. Nature 274: 362-364

Smith, K. L. Jr (1982). Zooplankton of a bathyl benthic boundary layer: in situ rates of oxygen consumption and ammonium excretion. Limnol. Oceanogr. 27: 461-471

Smith, K. L. Jr, Brown, N. O. (1983). Oxygen consumption of pelagic juveniles and demersal adults of the deep-sea fish Sebastolobus altivelis, measured at depth. Mar. Biol. 76 : 325-332

Smith, K. L. Jr, Hessler, R. R. (1974). Respiration of benthopelagic fishes: in situ measurements at 1230 meters. Science 184: 72-73

Smith, K. L. Jr, Laver, M. B. (1981). Respiration of the bathypelagic fish Cyclothone acclinidens. Mar. Biol. 61 261-266

Smith, K. L. Jr, Teal, J. M. (1973). Temperature and pressure effects on respiration of thecosomatous pteropods. Deep Sea Res. 20: $853-858$

Somero, G. N. (1991). Hydrostatic pressure and adaptations to the deep sea. In: Prosser, C. L. (ed.) Environmental and metabolic animal physiology. Wiley, New York, p. 167-204

Somero, G. N. (1992). Adaptations to high hydrostatic pressure. A. Rev. Physiol. 54: 557-577

Strickland, J. D. H., Parsons, T R. (1972). A practical handbook of seawater analysis, 2nd edn. Bull. Fish. Res. Bd Can. 167: 1-31.0 
Swezey, R. R., Somero, G. N. (1982). Polymerization thermodynamics and structural stabilities of skeletal muscle actins from vertebrates adapted to different temperatures and pressures. Biochemistry 21: 4496-4503

Swezey, R. R., Somero, G. N. (1985). Pressure effects on actin self-assembly: interspecific differences in the equilibrium and kinetics of the $G$ to $F$ transformation. Biochemistry 24 : $852-860$

Teal, J. M. (1971). Pressure effects on the respiration of vertically migrating decapod Crustacea. Am. Zool. 11: 571-576

Torres, J. J. (1984). Relationship of oxygen consumption to swimming speed in Euphausia pacifica. II. Drag, efficiency and a comparison with other swimming organisms. Mar. Biol. 78: 231-237

Torres, J. J., Belman, B. W., Childress, J. J. (1979). Oxygen consumption rates of mid-water fishes as a function of depth of occurrence. Deep Sea Res. 26: 185-197

Torres, J. J., Childress, J. J. (1983). The relationship of oxygen consumption to swimming speed in Euphausia pacifica. I. The effects of temperature and pressure. Mar. Biol. 74: $79-86$

Torres, J. J., Somero, G. N. (1988). Metabolism, enzymic activities and cold adaptation in Antarctic mesopelagic fishes. Mar. Biol. 98: 169-180

This article was submitted to the editor
Tucker, V. A. (1970). Energetic cost of locomotion in animals. Comp. Biochem. Physiol. 34: 841-846

Wiebe, P. H., Madin, L. P., Haury, L. R., Harbison, G. R. Philbin, L. M. (1979). Diel vertical migration by Salpa aspera and its potential for large-scale partıculate organic matter transport to the deep-sea. Mar. Biol. 53: 249-255

Yayanos, A. A. (1978). Recovery and maintenance of live amphipods at a pressure of 580 bars from an ocean depth of $5700 \mathrm{~m}$. Science 200:1056-1059

Youngbluth, M. J. (1984). Manned submersibles and sophisticated instrumentation: tools for oceanographic research. In: Proceedings of SUBTECH '83 Symposium. Society for Underwater Technology, London, p. 335-344

Youngbluth, M. J., Kremer, P., Bailey, T G., Jacoby, C. A (1988). Chemical composition, metabolic rates and feeding behavior of the midwater ctenophore Bathocyroe fosteri. Mar. Biol. 98: 87-94

Youngbluth, M. J., Bailey, T. G., Jacoby, C. A. (1990). Biological explorations in the mid-ocean realm: food webs, particle flux, and technological advancements. In: Lin, Y. C., Shida, K. K. (eds.) Man in the sea, Vol. II. Best Publishing, San Pedro, CA, p. 191-208

Zar, J. H. (1984). Biostatistical analysis, 2nd edn. Prentice Hall, Englewood Cliffs, NJ

Manuscript first received: December 14, 1993

Revised version accepted: July 22, 1994 